\title{
INFORMASI AKUNTANSI DAN NON AKUNTANSI PADA FENOMENA UNDERPRICING YANG TERJADI SAAT PENAWARAN UMUM SAHAM PERDANA PADA PERUSAHAAN YANG TERDAFTAR DI BURSA EFEK INDONESIA
}

\author{
Lydia Kurniawan \\ Sekolah Tinggi Ilmu Ekonomi Y.A.I. Jakarta \\ Email: Lydia_kurniawan8985@yahoo.com
}

\begin{abstract}
In order to expand their business in several ways, for example companies can offer their shares to the general public. Underpricing is a phenomenon that often appears and is experienced by companies that conduct an Initial Public Offering on the various stock exchanges in the world, where the IPO price is set lower than the true value of the company. Underpriced shares often occur because of information asymmetry or inequality of information that occurs in the group of investors who have information and a group of investors who do not have the information about the prospects of the issuer company. This study examined whether the age of the firm, firm size, and return on assets (ROA) affect the level of IPO underpricing on the company at the Indonesian Stock Exchange. This study was measured by Initial Return underpricing. The objects in this study are 32 companies that did the initial public offering in 2002 to 2004 at the Indonesia Stock Exchange and experienced under pricing . Conclusions from the study indicate that the companies age and their size variables are not shown to affect the dependent variable Underpricing, while the variable Return on Assets (ROA) Under pricing are shown to affect the dependent variable at a significant level of $5 \%$.
\end{abstract}

Keywords: Underpricing, Initial Public Offering (IPO), Company Age, Company size, and Return on Assets

\begin{abstract}
Abstrak: Dalam rangka untuk memperluas bisnis mereka dalam beberapa cara, Underpricing adalah fenomena yang sering muncul dan dialami oleh perusahaanperusahaan yang melakukan Penawaran Umum Perdana pada berbagai bursa saham di dunia, di mana harga IPO ditetapkan lebih rendah dari nilai sebenarnya dari perusahaan. Saham underpriced sering terjadi karena asimetri informasi atau ketimpangan informasi yang terjadi pada kelompok investor yang memiliki informasi dan sekelompok investor yang tidak memiliki informasi tentang prospek perusahaan emiten. Penelitian ini menguji apakah usia perusahaan, ukuran perusahaan, dan return on assets (ROA) mempengaruhi tingkat underpricing IPO pada perusahaan di Bursa Efek Indonesia. Penelitian ini diukur dengan Return underpricing awal. Benda-benda dalam penelitian ini adalah 32 perusahaan yang melakukan penawaran umum perdana pada tahun 2002 menjadi 2004 di Bursa Efek Indonesia dan berpengalaman di bawah harga. Kesimpulan dari penelitian ini menunjukkan bahwa perusahaan usia dan variabel ukuran mereka tidak terbukti mempengaruhi variabel dependen Underpricing, sedangkan variabel Return on Asset (ROA) Di bawah harga yang ditunjukkan untuk mempengaruhi variabel dependen pada tingkat signifikan 5\%.
\end{abstract}

Kata kunci: Underpricing, Initial Public Offering (IPO), umur perusahaan, ukuran perusahaan, Return on Assets 


\section{PENDAHULUAN}

Dalam suatu negara pasar modal memiliki peran strategis bagi pertumbuhan dan perkembangan ekonomi karena pasar modal merupakan suatu mediator bagi bertemunya dua pihak yaitu pihak yang memerlukan dana (perusahaan) dan investor. Salah satu cara untuk dapat memperoleh dana dari investor maka dapat dilakukan dengan menjual saham perusahaan kepada masyarakat (go-public).

Go public dapat dilakukan dengan cara menerbitkan saham baru atau disebut dengan penawaran umum saham perdana (Initial Public Offering / IPO). Perusahaan penerbit saham disebut emiten atau investee, sedangkan pembeli saham disebut investor. Transaksi penawaran umum penjualan saham pertama kali terjadi di pasar perdana (primary market), selanjutnya saham diperjualbelikan di bursa efek, yang disebut pasar sekunder (secondary market). Dua alasan utama mengapa perusahaan memutuskan go public (Rock, 1986 dalam Daljono, 2000) karena (1) pendiri perusahaan ingin mendiversifikasi portofolionya dan (2) perusahaan tidak mempunyai sumber dana alternatif untuk membiayai program investasinya.

Dalam IPO, emiten menginginkan harga penawaran saham perdana yang tinggi sedangkan penjamin emisi menginginkan harga yang murah begitu juga dengan investor. Perbedaan kepentingan inilah yang dapat menimbulkan kondisi underpricing. Tingkat underpricing secara tidak langsung menunjukkan besarnya biaya tambahan yang harus dikeluarkan emiten untuk go-public.

Di Indonesia terdapat kecenderungan underpricing saat IPO yaitu harga saham hari pertama di pasar sekunder lebih tinggi dari harga saham penawaran perdananya (Husnan, 1996 dalam Prihartanto, 2002). Dibeberapa negara berkembang di Amerika Latin gejala underpricing terjadi dalam jangka pendek, tetapi dalam jangka panjang kondisi sebaliknya (overpricing) yang terjadi (Aggarawal et, al., 1993 dalam Daljono, 2000). Kondisi underpricing tidak menguntungkan bagi perusahaan yang melakukan go public, karena dana yang diperoleh dari go public tidak maksimum. Sebaliknya bila terjadi overpricing maka investor akan merugi karena mereka tidak akan menerima return awal. Para pemilik perusahaan menginginkan agar dapat meminimalisir underpricing, karena terjadinya underpricing akan menyebabkan transfer kemakmuran (wealth) dari pemilik kepada para investor (Beatty, 1989 dalam Daljono, 2000).

Tingkat underpricing dapat dipengaruhi oleh faktor internal yang berasal dari dalam emiten maupun faktor eksternal, karena dalam prospektus selain menyajikan informasi akuntansi juga menyajikan informasi non akuntansi seperti underwriter (penjamin emisi efek), auditor independen, konsultan hukum, nilai penawaran saham, persentase saham yang ditawarkan, umur perusahaan, ukuran perusahaan dan informasi lainnya. Informasi non akuntansi digunakan oleh investor dalam pembuatan keputusan investasi di pasar modal, tetapi lain lagi dengan di Indonesia yang mayoritas para investornya tidak menggunakan informasi non akuntansi dalam investasi.

Penelitian ini ingin diketahui faktor - faktor yang mempengaruhi kecenderungan underpricing saham perdana dan yang diteliti adalah variabel yang masih sedikit diteliti dan hasilnya masih saling bertentangan, yaitu umur perusahaan, ukuran perusahaan dan Return on Assets (ROA) untuk diuji apakah berpengaruh signifikan secara parsial terhadap fenomena underpricing yang terjadi di Indonesia 


\section{KAJIAN TEORI}

Pasar Modal. Ada beberapa pengertian dari pasar modal, diantaranya adalah: (1) Menurut kamus pasar uang dan modal dalam Dahlan Siamat (2005: 487) "Pasar kongkret atau abstrak yang mempertemukan pihak yang menawarkan dan yang memerlukan dana jangka panjang yaitu jangka satu tahun keatas.” (2) Menurut David L. Scoel dalam Dahlan Siamat (2005 : 487) "Pasar untuk dana jangka panjang, dimana saham biasa, saham preferen, dan obligasi diperdagangkan.” (3) Menurut Undang-Undang Pasar Modal Nomor 8 Tahun 1995 dalam Tjiptono Darmadji (2006 : 2) "Kegiatan yang bersangkutan dengan penawaran umum dan perdagangan efek, perusahaan publik yang berkaitan dengan efek yang diterbitkannya serta lembaga dan profesi yang berkaitan dengan efek.”

Jenis Pasar Modal Menurut Sunariyah (2003 : 12 - 13), terbagi menjadi dua yaitu : (1) Pasar Perdana (Primary Market), "Penawaran saham dari suatu perusahaan yang menerbitkan saham (emiten) kepada pemodal selama waktu yang ditetapkan oleh pihak sebelum saham tersebut diperdagangkan di pasar sekunder." (2) Pasar Sekunder (Secondary Market), "Sebagai perdagangan saham setelah melewati masa penawaran pada pasar perdana.”

Pasar Modal mempunyai peranan penting dalam suatu negara, yang pada dasarnya mempunyai kesamaan antara satu negara dengan negara yang lain, yaitu bertujuan menciptakan fasilitas bagi keperluan industri dan keseluruhan aspek dalam memenuhi permintaan dan penawaran modal.

Menurut Panduan Investasi di Pasar Modal BAPEPAM (2003 : 2 - 4), peranan pasar modal pada suatu negara dapat dilihat dari lima segi berikut ini: (1) Pasar Modal merupakan wahana pengalokasian dana secara efisien, (2) Pasar Modal sebagai alternatif investasi, (3) Memungkinkan para investor memiliki perusahaan yang sehat dan berprospek baik, (4) Pelaksanaan manajemen perusahaan secara profesional dan transparan, dan (5) Peningkatan aktivitas ekonomi nasional.

Penawaran Umum (Public Issue). Penawaran umum atau sering pula disebut go public menurut Tjiptono Darmadji (2006: 73) adalah "Kegiatan penawaran saham atau efek lainnya yang dilakukan oleh emiten (perusahaan yang akan go public) untuk menjual saham atau efek kepada masyarakat berdasarkan tata cara yang diatur oleh UndangUndang Pasar Modal dan Peraturan Pelaksanaannya.”

Untuk go public perusahaan perlu melakukan persiapan internal dan menyiapkan dokumentasi sesuai dengan persyaratan untuk go public atau penawaran umum serta memenuhi semua persyaratan yang ditetapkan Bapepam. Dana yang diperoleh dari go public menurut Tjiptono Darmadji (2006: 79) digunakan perusahaan untuk :1) Ekspansi atau perluasan, 2) Memperbaiki struktur permodalan, 3) Meningkatkan investasi di anak perusahaan, 4) Melunasi sebagian hutang, 5) Menambah modal kerja

Menurut Tjiptono Darmadji (2006: 78) ada beberapa konsekuensi yang ditanggung perusahaan bila melakukan penawaran umum, yaitu: (1) Keharusan untuk melakukan keterbukaan (full disclosure), (2) Keharusan untuk mengikuti peraturan-peraturan pasar modal mengenai kewajiban pelaporan, (3) Gaya manajemen perusahaan berubah dari informal menjadi formal, (4) Kewajiban membayar deviden bila perusahaan mendapat laba, (5) Senantiasa berusaha meningkatkan tingkat pertumbuhan perusahaan. 
Initial Public Offering (IPO) adalah penjualan saham oleh perusahaan untuk pertama kali. Pada penjualan saham perdana ini perusahaan akan menerima uang tunai dan keuntungan dari selisih nilai nominal saham dengan harga saham pada pasar perdana.

Menurut Dahlan Siamat (2005: 500) Proses penawaran saham perdana yang harus dilalui oleh perusahaan yang ingin melakukan IPO adalah sebagai berikut: (1) Perusahaan yang akan menerbitkan efek (emiten atau issuer) menyampaikan pernyataan maksud (letter on intent) kepada Bapepam, (2) Emiten menghubungi dan menunjuk underwriter serta lembaga penunjang emisi lainnya, (3) Emiten dan underwriter mempersiapkan dokumen pernyataan pendaftaran emisi efek berikut lampiran dan dokumen emisi lainnya, (4) Emiten melalui underwriter menyampaikan pernyataan pendaftaran emisi efek kepada Bapepam, (5) Bapepam melakukan penelaahan kesesuaian dokumen emisi dengan ketentuan yang berlaku, (6) Ijin emisi diberikan oleh Bapepam bilamana semua dokumen emisi telah lengkap dan memenuhi ketentuan, (7) Pengumuman dan pendistribusian prospektus. Dalam prospektus tersebut memuat informasi yang perlu diketahui calon investor antara lain: (a) Tujuan penawaran, (b) Keterangan tentang perseroan antara lain riwayat perusahaan dan susunan Dewan Direksi dan Dewan Komisaris, (c) Masa Penawaran, (d) Tanggal penjatahan, (e) Tanggal pengembalian uang pesanan, (f) Tanggal pencatatan di bursa, (g) Harga, jumlah dan jenis saham yang ditawarkan, (h) Nama-nama penjamin emisi yang terdiri atas: penjamin utama, penjamin pelaksana, penjamin peserta, (i) Ikhtisar keuangan dan rasio-rasio keuangan perusahaan, (j) Kegiatan dan prospek usaha perusahaan, (k) Struktur permodalan perusahaan sebelum dan setelah emisi, (l) Faktorfaktor resiko yang mungkin dihadapi dalam usaha emiten, (m) Persyaratan dan tata cara pemesanan efek, (n) Perpajakan, (o) Nama-nama dan alamat agen penjual, (8) Emiten dan underwriter melakukan penawaran efek melalui pasar perdana, (9) Penjatahan saham, (10) Pengembalian uang kepada pemesan (refund), (11) Penyerahan sertifikat efek, (12) Pencatatan saham di bursa.

Underpricing. Daljono (2000: 556) Dalam proses go public sebelum saham diperdagangkan di pasar sekunder, terlebih dahulu saham perusahaan yang go public dijual di pasar perdana. Harga saham yang dijual di pasar perdana (saat IPO) telah ditentukan terlebih dahulu atas kesepakatan antara emiten dengan underwriter, sedangkan harga di pasar sekunder ditentukan oleh mekanisme pasar (penawaran dan permintaan). Dalam dua mekanisme penentuan harga tersebut, sering terjadi perbedaan harga terhadap harga saham yang sama antara di pasar perdana dan di pasar sekunder. Apabila penentuan harga saat IPO secara signifikan lebih rendah dibanding dengan harga yang terjadi di pasar sekunder di hari pertama, maka terjadi apa yang disebut underpricing.

Terjadinya underpricing karena adanya asimetri informasi, yaitu: Antara Informed Investor dengan Uninformed Investor. Asimetri informasi terjadi pada kelompok investor yang memiliki informasi dan kelompok investor yang tidak memiliki informasi tentang prospek perusahaan emiten. Kelompok investor yang memiliki informasi lebih baik, akan membeli saham-saham IPO bila nantinya akan memberikan return. Sedangkan kelompok yang kurang memiliki informasi tentang prospek emiten, akan membeli saham secara sembarangan baik saham yang underpriced maupun saham yang overpriced. Karena lebih banyak mendapatkan kerugian, maka kelompok ini akan meninggalkan pasar perdana. Agar semua kelompok berpartisipasi dalam pasar perdana dan memungkinkan 
memperoleh return yang wajar serta dapat menutup kerugian akibat pembelian saham overpriced, maka saham IPO harus cukup underpriced.

Dalam hal ini underpricing diukur dengan menggunakan initial return. ( Ang, 1977 dalam Etty M. Nasser, 2006) "Return (kembalian) adalah tingkat keuntungan yang dinikmati pemodal atas investasi yang dilakukannya." Pengukuran Return Saham pasca IPO adalah dengan pengembalian awal (initial return) yang merupakan selisih harga penutupan saham (closing price) dari hasil pertama diperdagangkan dipasar sekunder (bursa) dengan harga perdana pada waktu beli dipasar perdana dibagi dengan harga perdana.

\section{Informasi Yang Berhubungan Dengan Underpricing}

a. Umur Perusahaan. Perusahaan yang lebih tua dipersepsikan sebagai perusahaan yang sudah tahan uji sehingga memiliki resiko rendah, dengan demikian pada umumnya makin banyak umur suatu perusahaan maka ada peluang initial return kian tinggi.

Selain itu umur perusahaan menunjukkan seberapa lama perusahaan mampu bertahan. Semakin lama umur perusahaan, maka semakin banyak informasi yang telah diperoleh masyarakat tentang perusahaan tersebut. Dengan demikian akan mengurangi adanya asimetri informasi, dan memperkecil ketidakapastian dimasa yang akan datang.

Menurut Charter \& Manaster (1990) dalam Etty M. Nasser (2006) mengemukakan bahwa usia perusahaan mempunyai pengaruh signifikan terhadap keuntungan return saham, khususnya pada saham IPO. Artinya kian lama perusahaan beroperasi akan memiliki kinerja yang baik. Berdasarkan penelitian Etty M. Nasser (2006), umur perusahaan dihitung dengan mengurangi tahun penawaran pada saat IPO dengan tahun pada saat perusahaan berdiri dan hasil penelitian Etty M. Nasser (2006) menunjukkan bahwa umur perusahaan tidak memiliki pengaruh yang cukup signifikan terhadap return awal.

b. Ukuran Perusahaan. Bagaimana Anda membedakan bisnis kecil dengan bisnis besar? Apakah indikator utamanya adalah penjualan? Bagaimana dengan pangsa pasar atau jumlah karyawan?

Menurut Small Business Administration (SBA), suatu agen federal yang secara langsung terlibat di sektor ekonomi, menganggap bisnis kecil (small business) adalah perusahaan yang dimlilki dan di kelola secara independen, tidak mendominasi dalam bidangnya, dan memenuhi ukuran standar tertentu atas laba atau jumlah karyawan. Sedangkan pengertian bisnis besar adalah perusahaan yang berbentuk entitas hukum dimana aktiva dan kewajiban terpisah dari pemiliknya. Kurtz \& Boone (2002:177 dan 201) Kesimpulannya perbedaan ukuran perusahaan antara bisnis kecil dan bisnis besar biasanya dalam bentuk organisasi, posisi pasar, kapabilitas karyawan, gaya manajerial, struktur organisasi dan sumber daya keuangan.

Dalam hal ini ukuran perusahaan yang diteliti adalah ukuran perusahaan yang diperbolehkan IPO yaitu perusahaan publik seperti yang terdapat pada pasal 1 angka 22 pasar modal, adalah "perseroan yang memiliki sekurangnya 300 pemegang saham dan memiliki sekurangnya Rp 3 Milyar.” Tjiptono Darmadji (2006: 72). Ukuran perusahaan turut menentukan tingkat kepercayaan investor. Semakin besar perusahaan, semakin dikenal masyarakat yang berarti semakin mudah untuk mendapatkan informasi mengenai perusahaan. Kemudahan mendapatkan informasi akan meningkatkan kepercayaan investor 
dan mengurangi faktor ketidakpastian yang berarti risiko underpricing lebih kecil dan ekspektasi initial return lebih rendah.

Berdasarkan penelitian Marihot H Tambunan (2006), ukuran perusahaan yang diprediksikan dengan total aktiva perusahaan, dan hitung dengan cara total aktiva sebelum IPO dibagi ekuitas. Hasil penelitiannya mengemukakan bahwa variabel ukuran perusahaan tidak terbukti memiliki pengaruh negatif terhadap underpricing saham perusahaan yang melakukan Penawaran Umum Perdana di Bursa Efek Jakarta.

c. Return On Assets (ROA). Menurut Imam Ghozali dan Mudrik Al Mansur (2002 : 79), Return On Assets (ROA) merupakan suatu rasio yang penting yang dapat digunakan untuk mengukur kemampuan perusahaan dengan investasi yang telah ditanamkan (asset yang dimilikinya) untuk mendapatkan laba. ROA menjadi salah satu pertimbangan investor di dalam melakukan investasi terhadap saham-saham di bursa.

Daljono (2000 : 562) mengatakan Rate of Return on Total Assets (ROA) dapat digunakan sebagai pengukur profitabilitas suatu perusahaan. Tingkat profitabilitas merupakan informasi tingkat keuntungan yang dicapai atau informasi mengenai efektifitas operasional perusahaan. Profitabilitas perusahaan yang tinggi akan mengurangi ketidakpastian IPO sehingga mengurangi tingkat underpricing.

Menurut Tjiptono Darmadji dan Hendy M. Fakhruddin (2006:200), return on assets (ROA) dihitung dengan pembagian antara laba bersih dengan total aset. Penelitian yang dilakukan oleh Imam Ghozali dan Mudrik Al Mansur (2002 : 79) membuktikan bahwa ROA berpengaruh negatif dan signifikan terhadap underpricing. Sedangkan menurut penelitian yang dilakukan oleh Daljono (2000), ROA tidak terbukti berpengaruh terhadap initial return. Menurut Daljono (2000), hal ini mungkin disebabkan para investor telah menduga bahwa laporan keuangan perusahaan yang melakukan IPO telah di mark-up untuk menunjukkan kriteria yang baik.

Hubungan Umur Perusahaan, Ukuran Perusahaan, dan Return On Assets (ROA) dengan Underpricing. Pada saat penawaran umum saham perdana para investor selain berhadapan dengan aspek fundamental (informasi akuntansi) seperti Return On Assets, Financial Leverage, solvency ratio dan masih terdapat beberapa informasi non-akuntansi yang sangat berpengaruh terhadap underpricing yang di ukur dengan return saham, diantaranya: reputasi penjamin emisi, reputasi auditor, persentase penawaran saham, umur perusahaan, ukuran perusahaan, nilai penawaran saham dan deviasi standar return. Informasi mengenai perusahaan baik berupa informasi akuntansi dan informasi non akuntansi secara terinci terdapat dalam prospektus.

Ketidakseimbangan informasi seringkali terjadi antara emiten den underwriter maunpun investor pada saat IPO. Untuk mengurangi adanya asimetri informasi maka perusahaan yang akan go public menerbitkan prospektus yang berisi berbagai informasi perusahan yang bersangkutan. Studi mengenai perilaku para investor dalam pembuatan keputusan investasi di pasar modal dengan menggunakan informasi prospektus, baik yang berkaitan dengan informasi akuntansi (keuangan) maupun informasi non akuntansi (non keuangan) merupakan fenomena yang menarik bagi para peneliti keuangan di Indonesia.

Penelitian Etty M. Nasser (2006) menunjukkan bahwa kenaikan atau penurunan return awal tidak memiliki pengaruh yang cukup signifikan terhadap umur perusahaan dan ukuran perusahaan. Imam Ghozali dan Mudrik Al Mansur (2002) menunjukan variabel 
skala/ukuran perusahaan, umur perusahaan tidak berpengaruh terhadap underpricing sedangkan ROA berpengaruh secara signifikan negatif terhadap underpricing

\section{METODE}

Objek Penelitian. Satuan pengamatan yang menjadi objek penelitian ini adalah perusahaan yang melakukan penawaran umum saham perdana di Bursa Efek Indonseia (BEI) pada tahun 2002 sampai dengan tahun 2004.

Populasi dan Sampel Penelitian. Populasi pada penelitian ini adalah perusahaan yang melakukan penawaran umum saham perdana di Bursa Efek Indonseia (BEI) pada tahun 2002 sampai dengan tahun 2004. Teknik pengambilan sampling dilakukan Purposive sampling yaitu teknik pemilihan sampel yang dipilih dengan cermat sehingga relevan dengan rancangan penelitian dan sesuai dengan kriteria yang diharapkan peneliti. Kriteria yang akan dijadikan objek penelitian ini adalah perusahaan yang melakukan penawaran umum (IPO) di BEI pada tahun 2002 sampai dengan tahun 2004 yang mengalami underpricing. Berdasarkan kriteria sampel yang digunakan maka diperoleh sampel sebanyak 32 perusahaan yang digunakan sebagai sampel dalam penelitian ini.

Tabel 1. Proses Pemilihan Sampel

\begin{tabular}{ccccc}
\hline No & Tahun & $\begin{array}{c}\text { Jumlah Perusahaan } \\
\text { IPO }\end{array}$ & $\begin{array}{c}\text { Jumlah Perusahaan } \\
\text { Tidak Underpricing }\end{array}$ & $\begin{array}{c}\text { Jumlah Perusahaan } \\
\text { Underpricing }\end{array}$ \\
\hline 1 & 2002 & 22 & 4 & 18 \\
2 & 2003 & 6 & 1 & 5 \\
3 & 2004 & 12 & 3 & 9 \\
& Jumlah & 40 & 8 & 32 \\
\hline
\end{tabular}

Operasionalisasi Variabel. Berdasarkan judul dan hipotesis penelitian, maka variabelvariabel dalam penelitian ini dapat dijabarkan sebagai berikut:

1) Variabel dependen - Underpricing $(\mathrm{Y})$

Besarnya underpricing diukur dengan initial return yaitu perbandingan antara selisih harga saham pada hari pertama penutupan (closing price) di pasar sekunder dengan harga saham pada penawaran perdana (offering price) di pasar perdana dibagi dengan harga saham pada penawaran perdana.

$$
\mathrm{UP}=\frac{\mathrm{Pt} 1-\mathrm{Pt} 0}{\mathrm{Pt} 0}
$$

dimana : Pt1 adalah harga penutupan (closing price) pada hari pertama di pasar sekunder

Pt0 adalah harga penawaran perdana (offering price)

2) Variabel independen yang digunakan:

a. Umur Perusahaan (AGE).

AGE diukur berdasarkan pengalaman perusahaan dengan asumsi perusahaan yang telah lebih tua dianggap memiliki investasi yang sedikit lebih berisiko pada 
keputusan investasi. Umur perusahaan dihitung menurut lamanya perusahaan beroperasi mulai perusahaan berdiri sampai listing di BEI.

AGE = Tahun pendirian - Tahun IPO

b. Ukuran Perusahaan (SIZE) sebagai variabel independen.

SIZE diukur dari hasil pembagian total aktiva perusahaan sebelum perusahaan listing dengan nilai ekuitas perusahaan sebelum perusahaan listing.

$$
\text { SIZE }=\frac{\text { Total Aktiva }}{\text { Total Equity }}
$$

c. Return On Assets (ROA) sebagai variabel independen.

ROA dihitung dari hasil pembagian laba bersih setelah pajak atau Net Income After Tax dengan total aktiva sebelum perusahaan listing.

$$
\text { ROA }=\frac{\text { Net Income After Tax }}{\text { Total Aktiva }}
$$

Metode Analisis. Data yang digunakan adalah data sekunder dan data cross-sectional, karena pengumpulan data dilakukan dengan observasi dan data yang digunakan adalah pada waktu tertentu yaitu pada saat perusahaan melakukan penawaran umum saham perdana dan mengalami underpricing.

Dalam penelitian ini data yang diambil dan diperlukan adalah: (1) Nama-nama perusahaan yang melakukan IPO, tanggal listing, dan tanggal pendirian masing-masing perusahaan, (2) Harga per lembar saham, closing price saham di hari pertama masingmasing perusahaan, dan (3) Laba (rugi) bersih sebelum pajak, total assets, total ekuitas masing-masing perusahaan.

Data-data tersebut diperoleh dari Indonesian Capital Market Directory tahun 20022005, untuk data laba (rugi) bersih sebelum pajak, total assets, total ekuitas, nama-nama perusahaan dan tanggal pendirian perusahaan. Jakarta Stock Exchange Fact Book tahun 2002-2005, untuk data nama-nama perusahaan yang melakukan IPO, tanggal listing, harga per lembar saham. Data-data pendukung lainnya diperoleh melalui download dari http//www.jsx.co.id, http//www.goggle.com dan sumber-sumber lain yang diperlukan.

Untuk menguji hipotesis yang diajukan peneliti maka akan dilakukan uji korelasi, koefisien determinasi, uji statistik F , uji statistik t. Untuk mengetahui dan mengukur keterikatan antara faktor-faktor yang mempengaruhi underpricing saham IPO, maka variabel terdiri dari satu variabel dependen dan tiga variabel independen. Dalam persamaan regresi, variabel yang diamati diterangkan oleh sebuah fungsi dari beberapa variabel penjelas baik dalam bentuk linear.

Adapun model fungsi yang dapat dituliskan sebagai berikut :

$$
\begin{aligned}
& \mathrm{Y}=\mathrm{a}+\mathrm{b}_{1} \mathrm{X}_{1}+\varepsilon \\
& \mathrm{Y}=\mathrm{a}+\mathrm{b}_{2} \mathrm{X}_{2}+\varepsilon \\
& \mathrm{Y}=\mathrm{a}+\mathrm{b}_{3} \mathrm{X}_{3}+\varepsilon
\end{aligned}
$$

Dimana: Y (UP) = Underpricing, sebagai variabel dependen, $\mathrm{a}=$ Konstanta, b1b3 = Koefisien regresi dari masing-masing variabel independent, $X_{1}$ (AGE) $=$ Umur perusahaan, $\mathrm{X}_{2}(\mathrm{SIZE})=$ Ukuran Perusahaan, $\mathrm{X}_{3}(\mathrm{ROA})=$ Return On Asset, e = error 


\section{HASIL DAN PEMBAHASAN}

Pengaruh umur perusahaan, ukuran perusahaan dan return on asset terhadap underpricing saham perusahaan-perusahaan yang terdaftar dalam Indeks LQ-45

Dari perhitungan dengan menggunakan tingkat keyakinan $95 \%, \alpha=5 \%$, derajat bebas pengujian adalah $\mathrm{n}-\mathrm{k}=32-4=28$ ( $\mathrm{n}$ adalah jumlah kasus dan $\mathrm{k}$ adalah jumlah variabel independen), hasil diperoleh untuk t tabel sebesar 2,042.

Tabel 2. Regresi Linear Sederhana ( Pengaruh $\mathrm{X}_{1}$ terhadap Y)

\begin{tabular}{|c|c|c|c|c|c|c|c|c|}
\hline \multicolumn{9}{|c|}{ Coefficients $^{\mathrm{a}}$} \\
\hline & & \multicolumn{2}{|c|}{$\begin{array}{l}\text { Unstandardized } \\
\text { Coefficients }\end{array}$} & $\begin{array}{l}\text { Standardized } \\
\text { Coefficients }\end{array}$ & & & \multicolumn{2}{|c|}{$\begin{array}{l}\text { Collinearity } \\
\text { Statistics }\end{array}$} \\
\hline & Model & B & $\begin{array}{l}\text { Std. } \\
\text { Error }\end{array}$ & & $\mathrm{t}$ & Sig. & Tolerance & VIF \\
\hline 1 & (Constant) & .369 & .129 & & 2.858 & .008 & & \\
\hline & AGE & -.044 & .101 & -.079 & -.432 & .669 & 1.000 & 1.000 \\
\hline
\end{tabular}

a. Dependent Variable: UP

Tabel 3. Regresi Linear Sederhana ( Pengaruh $\mathrm{X}_{2}$ terhadap Y)

\begin{tabular}{|c|c|c|c|c|c|c|c|c|}
\hline \multicolumn{9}{|c|}{ Coefficients $^{\mathrm{a}}$} \\
\hline & \multirow[b]{2}{*}{ Model } & \multicolumn{2}{|c|}{$\begin{array}{c}\text { Unstandardized } \\
\text { Coefficients }\end{array}$} & \multirow[t]{2}{*}{$\begin{array}{c}\text { Standardized } \\
\text { Coefficients }\end{array}$} & \multirow[b]{2}{*}{$\mathrm{t}$} & \multirow[b]{2}{*}{ Sig. } & \multicolumn{2}{|c|}{$\begin{array}{l}\text { Collinearity } \\
\text { Statistics }\end{array}$} \\
\hline & & B & $\begin{array}{l}\text { Std. } \\
\text { Error }\end{array}$ & & & & Tolerance & VIF \\
\hline 1 & $\begin{array}{l}\text { (Constant) } \\
\text { SIZE }\end{array}$ & $\begin{array}{l}.368 \\
-.098\end{array}$ & $\begin{array}{l}.070 \\
.100\end{array}$ & -.175 & $\begin{array}{l}5.278 \\
-.975\end{array}$ & $\begin{array}{l}.000 \\
.337\end{array}$ & 1.000 & 1.000 \\
\hline
\end{tabular}

a. Dependent Variable: UP

Tabel 4. Regresi Linear Sederhana ( Pengaruh $\mathrm{X}_{3}$ terhadap $\mathrm{Y}$ )

\begin{tabular}{|c|c|c|c|c|c|c|c|c|}
\hline \multicolumn{9}{|c|}{ Coefficients $^{\mathrm{a}}$} \\
\hline & \multirow[b]{2}{*}{ Model } & \multicolumn{2}{|c|}{$\begin{array}{l}\text { Unstandardized } \\
\text { Coefficients }\end{array}$} & \multirow[t]{2}{*}{$\begin{array}{l}\text { Standardized } \\
\text { Coefficients }\end{array}$} & \multirow[b]{2}{*}{$\mathrm{t}$} & \multirow[b]{2}{*}{ Sig. } & \multicolumn{2}{|c|}{$\begin{array}{l}\text { Collinearity } \\
\text { Statistics }\end{array}$} \\
\hline & & $\mathrm{B}$ & $\begin{array}{l}\text { Std. } \\
\text { Error }\end{array}$ & & & & Tolerance & VIF \\
\hline 1 & (Constant) & .389 & .052 & & 7.416 & .000 & & \\
\hline & ROA & - 1.930 & .822 & -.394 & -2.348 & .026 & 1.000 & 1.000 \\
\hline
\end{tabular}

a. Dependent Variable: UP

Hasil perbandingan antara t hitung dengan t tabel dapat dilihat pada Tabel 5.

Umur Perusahaan tidak berpengaruh signifikan terhadap Underpricing. Penelitian ini mendukung penelitian yang dilakukan oleh Etty M. Nasser (2006) dan Daljono (2000). Hal ini membuktikan bahwa perusahaan yang lebih tua yang umumnya dipersepsikan sebagai perusahaan yang sudah tahan uji sehingga memiliki resiko rendah, dengan 
demikian pada umumnya makin banyak umur suatu perusahaan maka ada peluang initial return kian tinggi tidak terbukti karena umumnya investor membeli saham tidak bergantung pada umur perusahaan tersebut. Atau dapat dikatakan para investor di pasar perdana, tidak menggunakan informasi non-akuntansi dalam keputusan investasi.

Tabel 5. Resume hasil uji t variabel bebas terhadap Underpricing

\begin{tabular}{ccccc}
\hline Variabel & t- hitung & t-tabel & Signifikansi & \multicolumn{1}{c}{ Interpretasi } \\
\hline AGE & $-0,432$ & $-2,042$ & $\begin{array}{c}\text { Tidak } \\
\text { signifikan }\end{array}$ & $\begin{array}{l}\text { Ho diterima, Umur perusahaan tidak } \\
\text { berpengaruh terhadap Underpricing }\end{array}$ \\
SIZE & $-0,975$ & $-2,042$ & $\begin{array}{c}\text { Tidak } \\
\text { signifikan }\end{array}$ & $\begin{array}{l}\text { Ho diterima, Ukuran Perusahaan } \\
\text { tidak berpengaruh terhadap } \\
\text { Underpricing }\end{array}$ \\
ROA & $-2,348$ & $-2,042$ & Signifikan & $\begin{array}{l}\text { Ho ditolak, Berarti Return On Assets } \\
\text { berpengaruh negatif signifikan } \\
\text { (sedang) terhadap Underpricing }\end{array}$ \\
\hline
\end{tabular}

Ukuran Perusahaan tidak berpengaruh signifikan terhadap Underpricing. Penelitian ini mendukung penelitian yang di lakukan oleh Etty M. Nasser (2006), Imam Ghozali dan Mudrik Al Mansur (2002) yang dalam hasil penelitiannya ukuran perusahaan tidak berpengaruh terhadap underpricing, yang berarti seringkali investor dalam membeli saham kurang memperhatikan ukuran perusahaan, tapi lebih kepada variabel-variabel lainnya. Tapi bertentangan dengan penelitian Marihot H Tambunan (2006), bahwa variabel ukuran perusahaan mempunyai pengaruh terhadap underpricing saham perusahaan yang melakukan Penawaran Umum Perdana di Bursa Efek Indonesia .

Return On Assets berpengaruh cukup signifikan terhadap Underpricing. Penelitian ini mendukung penelitian yang dilakukkan oleh Imam Ghozali dan Mudrik Al Mansur (2002) sekaligus tidak mendukung penelitian yang dilakukan oleh Daljono (2000).

\section{PENUTUP}

Simpulan. Penelitian ini menghasilkan bahwa secara parsial umur perusahaan dan ukuran perusahaan tidak terbukti mempengaruhi tingkat Underpricing saham saat IPO pada perusahaan yang terdaftar di Bursa Efek Indonesia tetapi variabel Return On Assets terbukti mempengaruhi (signifikan negatif) terhadap tingkat Underpricing.

Keterbatasan penelitian ini hanya menggunakan tiga variabel yaitu Umur Perusahaan, Ukuran Perusahaan, dan Return On Assets sehingga belum memberikan hasil yang maksimal. Karena faktor - faktor yang mempengaruhi underpricing sangat banyak, baik dari segi faktor akuntansi dan faktor non akuntansi. Sehingga peneliti dapat memberikan beberapa saran yang dapat dijadikan masukan dalam pengembangan penelitian lebih lanjut.

Saran. Adapun saran dari peneliti adalah menggunakan variabel-variabel lain yang diperkirakan akan berpengaruh terhadap underpricing, seperti reputasi manajer, rasio keuangan lainnya, seperti EPS, PER, reputasi underwriter, reputasi auditor, nilai 
penawaran saham, dan lain-lain. Selain itu diharapkan juga untuk menganalisis dengan memperhatikan karakteristik industri perusahaan seperti manufaktur, perbankan dan perusahaan non manufaktur lainnya. Karena secara teoritis, karakteristik setiap perusahaan berbeda. Sedangkan Untuk investor yang akan melakukan investasi terhadap perusahaan yang melakukan IPO agar juga memperhatikan faktor fundamental seperti : kondisi sosial, kondisi politik, dan kondisi keamanan. Dan dalam menghitung initial return dapat menggunakan perbandingan antara selisih harga saham pada hari ke sepuluh, kelima belas penutupan setelah IPO atau return setahun di pasar sekunder dengan harga saham pada penawaran perdana di pasar perdana dibagi dengan harga saham pada penawaran perdana.

\section{DAFTAR RUJUKAN}

Badan Pengawas Pasar Modal. (2003) Panduan investasi pasar modal. Jakarta Badan Pengawas Pasar Modal.

(2003). Sekilas pasar modal indonesia. Jakarta : Badan Pengawas Pasar Modal Departemen Keuangan Republik Indonesia.

Bursa Efek Jakarta. (2003). Panduan go public. Jakarta: Jakarta Stock Exchange.

Bursa Efek Jakarta. (2002). Indonesian Capital Market Directory. Institute for Economic and Financial Research. (2003). Indonesian Capital Market Directory. Institute for Economic and Financial Research.

(2004). Indonesian Capital Market Directory. Institute for Economic and Financial Research. (2005). Indonesian Capital Market Directory. Institute for Economic and Financial Research.

Daljono. (2000). "Analisis faktor-faktor yang mempengaruhi initial return saham yang listing di BEJ tahun 1990-1997”, Simposium Nasional Akuntansi 3, Depok 5 September, hal 556-572.

Darmadji, Tjiptono dan Hendy M. Fakhruddin (2006) Pasar modal di Indonesia: pendekatan Tanya-jawab, Edisi 2, Jakarta: Salemba Empat.

Ghozali, Imam dan Mudrik Al Mansur. (2002) "Analisis faktor-faktor yang mempengaruhi tingkat underpriced di Bursa Efek Jakarta”, Jurnal Bisnis dan Akuntansi, Vol.4, (1) hal 74-78.

(2001) Aplikasi analisis multivariate dengan program SPSS. Semarang: Badan Penerbit Universitas Diponegoro.

Nasser, Etty M. (2006) "Pengaruh informasi non akuntansi terhadap initial return IPO perusahaan go publik”, Jurnal Ekonomi STEI ( Sekolah Tinggi Ilmu Ekonomi Indonesia), No. 1/Th.XV/32/Januari-April, hal 85-104.

Siamat, Dahlan. (2001) Manajemen lembaga keuangan.Jakarta.Lembaga Penerbit Fakultas Ekonomi Univesitas Indonesia.

Sugiono. (2008) Metode penelitian bisnis, Bandung: Alfabeta.

Sujianto, Agus Eko. (2007) Aplikasi statistik dengan SPSS untuk pemula, Jakarta: Prestasi Pustaka.

Sunariyah. (2003) Pengantar pengetahuan pasar modal, Edisi ke-3, Yogyakarta: YKPN. 
Tambunan, Marihot H. (2006) "Analisis beberapa faktor yang mempengaruhi underpricing saham perusahaan yang melakukan penawaran umum saham perdana di Bursa Efek Jakarta (BEJ), Jurnal Skripsi, Bandung: Unpad.

Triani, Apriliani dan Nikmah. (2006) "Reputasi penjamin emisi, reputasi auditor, persentase penjamin emisi, ukuran perusahaan dan fenomena underpricing : studi empiris pada Bursa Efek Jakarta“. Simposium Nasional Akuntansi 9, Padang 23 26 Agustus . 